ISSN 1392-3196 / e-ISSN 2335-8947

Zemdirbyste-Agriculture, vol. 103, No. 4 (2016), p. 355-362

DOI 10.13080/z-a.2016.103.045

\title{
The influence of composts on yield and chemical elements of winter wheat and spring barley
}

\author{
Gediminas STAUGAITIS ${ }^{1}$, Ieva NARUTYTE ${ }^{1}$, Jonas ARBAČAUSKAS ${ }^{1}$, \\ Zigmas VAIŠVILA ${ }^{1}$, Kęstutis RAINYS ${ }^{2}$, Romas MAŽEIKA ${ }^{1}$, Aistè MASEVIČIENE ${ }^{1}$, \\ Lina ŽIČKIENE ${ }^{1}$, Donatas ŠUMSKIS ${ }^{1}$ \\ ${ }^{1}$ Agrochemical Research Laboratory, Lithuanian Research Centre for Agriculture and Forestry \\ Savanorių 287, Kaunas, Lithuania \\ E-mail: agrolab@agrolab.lt \\ ${ }^{2}$ Elmininkai Experimental Station, Lithuanian Research Centre for Agriculture and Forestry \\ Elmininkai, Anykščiai distr., Lithuania
}

\begin{abstract}
In 2013-2014, research was carried out on a Bathihypogleyi-Haplic Luvisol (LVh-gld-w) soil with predominant sandy loam and $\mathrm{pH}_{\mathrm{KCl}} 4.9-5.2$ with a view to finding out how composts produced from sewage sludge, green waste and biogas production waste influenced grain and straw yields of winter wheat grown in the first year after compost incorporation and spring barley grown in the second year after incorporation as well as the concentrations of nitrogen, potassium and heavy metals in grain and straw. The field experiment was conducted in the fields of Elmininkai Experimental Station (Anykščiai distr., Eastern Lithuania) of the Lithuanian Research Centre for Agriculture and Forestry. The investigations proved that the composts incorporated without mineral fertilizer did not increase grain and straw of winter wheat grown in the first year after incorporation. During the second year, the composts increased the spring barley grain yield as follows: biogas - by $72.9 \%$, green waste $-68.6 \%$, cattle manure $-58.9 \%$ and sewage sludge $-45.2 \%$. The application of composts on the background of mineral fertilizers did not significantly increase winter wheat and spring barley grain and straw yields compared with mineral fertilizers. The concentration of chemical elements in plants depended on the compost degradation process in soil. During the first year after incorporation of composts, nitrogen $(\mathrm{N})$ concentration in winter wheat grain was increased by biogas, and during the second year - by sewage sludge and green waste composts in spring barley grain. Potassium (K) concentration in winter wheat and spring barley straw was increased by cattle manure, biogas and sewage sludge composts. During the first year, all composts increased phosphorus $(\mathrm{P})$ concentration in winter wheat straw. The concentrations of heavy metals $(\mathrm{Cd}, \mathrm{Ni}, \mathrm{Pb}, \mathrm{Zn}, \mathrm{Mn}$ and $\mathrm{Cu})$ in grain and straw were close to the background levels. The composts used in the study increased the content of nickel in winter wheat and spring barley grain and straw somewhat more significantly.
\end{abstract}

Key words: composts, grain, heavy metals, spring barley, straw, winter wheat.

\section{Introduction}

Each year the flows of biodegradable waste from agriculture, food industry, sludge purification installations and municipal green waste management units, etc. are increasing (Larney et al., 2008). One of the most popular ways of utilizing biodegradable waste is composting and using composts for plant fertilization (Uriah, Shehu, 2014). However, the value of composts produced from different kinds of biodegradable waste varies greatly (Fuchs et al., 2008; Carvalho, Marchi, 2015).

When technogenic waste such as sewage sludge, ash, mixed biodegradable municipal waste and residues from biogas production are used in compost production, soil and plants are often contaminated with heavy metals ( $\mathrm{Zn}, \mathrm{Mn}, \mathrm{Cu}, \mathrm{Ni}, \mathrm{Cd}$ and $\mathrm{Cr}$ ), which can pass to the food chain (Greger et al., 2007; Uriah, Shehu, 2014; Carvalho, Marchi, 2015). Quite often such composts include persistent organic pollutants: polycyclic aromatic hydrocarbons, di(ethylhexyl) phthalates, polychlorinated biphenyls, etc., which have a toxic effect on plants and are accumulated in soil (Paradelo et al., 2008). The least toxic are composts produced from plant material, however, their fertilizing value is not great (Paradelo et al., 2008; Tooba et al., 2014; Staugaitis et al., 2015 a). Long-term experience indicates that solid manure composts are among the most valuable; however, their high rate incorporation is associated with nitrogen pollution (Moral et al., 2009).

The experiments conducted with sewage sludge containing considerable levels of nitrogen, phosphorus and potassium suggest it has a more negative than positive effect, which is associated with the accumulation of heavy metals in plant produce and soil (Natal-daLuz et al., 2009). The experiments conducted on leaf lettuce indicated that the composts produced from mixed municipal waste and sewage sludge increased the content of nickel $(\mathrm{Ni})$ and lead $(\mathrm{Pb})$ in plants, and the composts of mixed municipal waste increased copper $(\mathrm{Cu})$ content as well (Staugaitis et al., 2015 a). In fact, Ni content in 
sewage sludge and mixed municipal waste composts is 4 times higher compared with green waste composts, $\mathrm{Pb}$ content is 4 and 8 times higher, respectively, and $\mathrm{Cu}$ content -8 and 14 times higher (Staugaitis et al., 2015 a). It was established that fertilization of crops with sewage sludge compost results in plants absorbing zinc ( $\mathrm{Zn})$ and accumulating it in their tissues more than $\mathrm{Cu}$, as $\mathrm{Zn}$ is more mobile and it is more difficult for plants to regulate the access of this element (Zheljazkov, Warman, 2004). Cadmium $(\mathrm{Cd})$ is particularly harmful. Its concentration in the cereals grown in unpolluted areas does not exceed $0.1 \mathrm{mg} \mathrm{kg}^{-1}$ as a rule and in the case of pollution it can reach $0.2 \mathrm{mg} \mathrm{kg}^{-1}$ and more. Contamination with $\mathrm{Cd}$ is often increased while using sewage sludge for fertilisation and the availability of this element to a plant is greater at lower soil $\mathrm{pH}$ values (Kirkham, 2006). Pb concentration in wheat ranges within $0.001-0.7$ as a rule and in barley it is $0.001-0.2 \mathrm{mg} \mathrm{kg}^{-1}$. The absorption of heavy metals in a plant is influenced by the content of other chemical elements in soil, their solubility and the relationship between them, e.g., calcium (Ca) deficiency increases $\mathrm{Cd}$ content and it is reduced by $\mathrm{Cu}$ and $\mathrm{Zn}$ (McLaughlin et al., 1999).

If we bring in higher content of nitrogen, phosphorus, potassium and organic matter with composts to improve soil properties (Staugaitis et al., $2015 \mathrm{~b}$ ), at the same time we bring in heavy metals that are longlasting pollutants and they cannot be removed from soil naturally (Navas, Lindhotfer, 2005).

The aim of our research was to establish how the composts produced from sewage sludge, green waste and biogas residues influence grain and straw yields of winter wheat and spring barley and the concentrations of nitrogen, phosphorus, potassium and heavy metals in them.

\section{Materials and methods}

Site description and experimental design. The field experiment was conducted in 2013-2014 in the fields of Elmininkai Experimental Station (Anykščiai

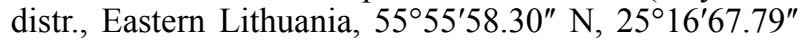
E) of the Lithuanian Research Centre for Agriculture and Forestry. The following experimental design was used: 1) without fertilizers, 2) cattle manure compost, 3) green waste compost, 4) biogas production waste compost, 5) sewage sludge compost, 6) fertilization with mineral fertilizer (winter wheat $-\mathrm{N}_{90} \mathrm{P}_{60} \mathrm{~K}_{90}$, spring barley $\left.\mathrm{N}_{60} \mathrm{P}_{40} \mathrm{~K}_{60}\right)$, 7) cattle manure compost + mineral fertilizer, 8) green waste compost + mineral fertilizer, 9) biogas production waste compost + mineral fertilizer and 10) sewage sludge compost + mineral fertilizer.

Description of composts used: cattle manure compost - compost of animal solid manure with straw; green waste compost - urban green waste compost produced from cut grass, tree leaves and a small portion of shredded branches; biogas production waste compost biogas residue compost produced from processing spent grain under anaerobic conditions; sewage sludge compost - sewage sludge from Vilnius municipality mixed with straw ( $15 \%$ by volume). The composts were incorporated into soil once - in August 2012. After the incorporation of fertilizers in the experiment, winter wheat cv. 'Ada' and after that spring barley cv. 'Luokè' were grown. Straw was removed from the field. The rates of composts were calculated based on the maximal permitted nitrogen rate of $170 \mathrm{~kg} \mathrm{ha}^{-1}$, as it was indicated in the EC Directive
91/676/EEC. Chemical composition of the composts and the amounts of nutrients and heavy metals incorporated together with them during the experiments are presented in Tables 1 and 2.

The mineral fertilizers used were ammonium nitrate, granular superphosphate and potassium chloride. Winter wheat was fertilized with phosphorus and potassium fertilizers in autumn before sowing and nitrogen was applied in spring when vegetation resumed (beginning of April). Spring barley was fertilized with mineral fertilizers in spring before sowing. Winter wheat was sown on 18 September 2012 and harvested on 2 August 2013, spring barley - on 3 May and 15 August 2014 , respectively.

Herbicides Accurate $^{\circledR}$ (a.i. metsulfuron methyl $200 \mathrm{~g} \mathrm{~kg}^{-1}$, rate $0.020 \mathrm{~kg} \mathrm{ha}^{-1}$ ) and Grodyl ${ }^{\circledR}$ (a.i. amidosulfuron $100 \mathrm{~g} \mathrm{~kg}^{-1}, 0.025 \mathrm{~kg} \mathrm{ha}^{-1}$ ) as well as fungicide Prosaro ${ }^{\circledR}$ (a.i. prothioconazole $125 \mathrm{~g} \mathrm{l}^{-1}$, tebuconazole $125 \mathrm{~g} \mathrm{l}^{-1}, 11 \mathrm{ha}^{-1}$ ) were applied on winter wheat. Herbicide Sekator ${ }^{\circledR}$ (a.i. amidosulfuron $100 \mathrm{~g}$ $\mathrm{l}^{-1}$, iodosulfuron-methyl-sodium $25 \mathrm{~g} \mathrm{l}^{-1}, 150 \mathrm{ml} \mathrm{ha}^{-1}$ ) and fungicide Falkon ${ }^{\circledR}$ Forte (a.i. spiroxamine $224 \mathrm{~g} \mathrm{l}^{-1}$, tebuconazole $148 \mathrm{~g} \mathrm{l}^{-1}$, triadimenol $53 \mathrm{~g} \mathrm{l}^{-1}, 0.8 \mathrm{l} \mathrm{ha}^{-1}$ ) were applied on spring barley.

Four replications of each treatment were used; the total size of the experimental plot was $72 \mathrm{~m}^{2}(12 \times$ $6 \mathrm{~m})$, harvested area $-22 \mathrm{~m}^{2}(10 \times 2.2 \mathrm{~m})$. The plots were arranged in four replication blocks.

Soil, composts and plant sampling and analytical methods. Soil samples for determination of agrochemical parameters were collected from $0-20 \mathrm{~cm}$ soil layer of the first and third replication plots before winter wheat sowing and incorporation of fertilizers. Compost samples for quality analyses were taken in two replications, each of which consisted of 20 discrete subsamples. During harvesting the grain yield collected from each experimental plot was weighed separately and the same day grain moisture content was determined. Grain samples for determination of chemical composition were collected from the first and third replications of treatments Nos. 1-5, for a large number of samples. Grain yield was expressed in moisture of $15 \%$ and straw yield - by the content of dry matter.

Soil $\mathrm{pH}_{\mathrm{KCl}}$ was determined in $1 \mathrm{~N} \mathrm{KCl}$ extract using potentiometric method, plant available phosphorus and potassium content - according to Egner-RiehmDomingo (A-L) method, organic carbon content - by dry combustion method. Dry matter in composts was determined in accordance with standard LST EN 13040:2008, organic matter - according to LST EN 13039:2012, total nitrogen - according to EN 13342:2000 using a nitrogen distiller, total phosphorus - according to standard LST EN 13650:2006, LST EN ISO 11885:2009 using a flame photometer and total potassium - according to LST EN 13650:2006 and LST ISO 9964-3:1998. Heavy metals in soil were determined in aqua regia, according to standards ISO 11466:1995, ISO 11047:1998 and ISO 22036:2008, in composts - LST EN 13650:2006, LST EN ISO 15586:2004 and LST EN ISO 11885:2009.

To determine the chemical composition of winter wheat and spring barley grain and straw the following procedure was used: ground plant mass was combusted in a muffle furnace at $550^{\circ} \mathrm{C}$ for 12 hours. Nitrogen concentration was determined using Kjeldahl method, potassium - by flame photometer. Phosphorus and heavy metals were analysed according to standard LST EN 15621:2012. 
Weather conditions. Meteorological conditions during the experimental period were assessed according to the data from Elmininkai Meteorological Station. To describe natural irrigation conditions during plant vegetation periods Selianinov's hydrothermal coefficient (HTC) was used, calculated according to the formula: $\mathrm{HTC}=\mathrm{H} /(0.1 * \Sigma \mathrm{T})$, where $\mathrm{H}$ represents precipitation during the analysed period, $\mathrm{mm}$; and $\Sigma \mathrm{T}$ stands for the sum of average daily temperatures higher than $10^{\circ} \mathrm{C}$ during the same period decreased 10 times (compared to evaporation rate - defines evaporation conditions). Vegetation periods according to HTC are divided into: HTC $>1.6$ - irrigation is excessive, HTC $=1.0 \ldots 1.5$ - optimal irrigation, HTC $=0.9 \ldots 0.8$ - weak drought, $\mathrm{HTC}=0.7 \ldots 0.6-$ moderate drought $($ arid $), \mathrm{HTC}=0.5$ ... 0.4 - heavy drought, HTC $<0.4$ - very heavy drought (Dirsè, Taparauskienè, 2010).

In September 2012, the mean daily temperatures were close to the multiannual average and the monthly rainfall was $6.4 \mathrm{~mm}$ lower than the multiannual average. The winter crop sown germinated well, branched and its vegetation continued until the first frosts at the beginning of December. During December-March slightly negative temperatures prevailed, the monthly rainfall ranged within $22.7-49.5 \mathrm{~mm}$, therefore, the winter crop survived well and its vegetation restarted at the beginning of April. In 2013 during the plant vegetation period (May-July) the sum of active temperatures was $1747.1^{\circ} \mathrm{C}$, rainfall amounted to $269.9 \mathrm{~mm}$. May was full of contrasts: the first ten day period was droughty $(\mathrm{HTC}=0)$ and during the second one excessive humidity was recorded (HTC $=5.70$ ), however, it did not have any marked effect on winter wheat. June was rather humid $(\mathrm{HTC}=1.46)$ and July was not humid enough (HTC $=0.94)$ (Fig.), nevertheless, these summer months were favourable for winter wheat growth and grain development.

In the beginning of May 2014, there was extensive rainfall after spring barley sowing, therefore,

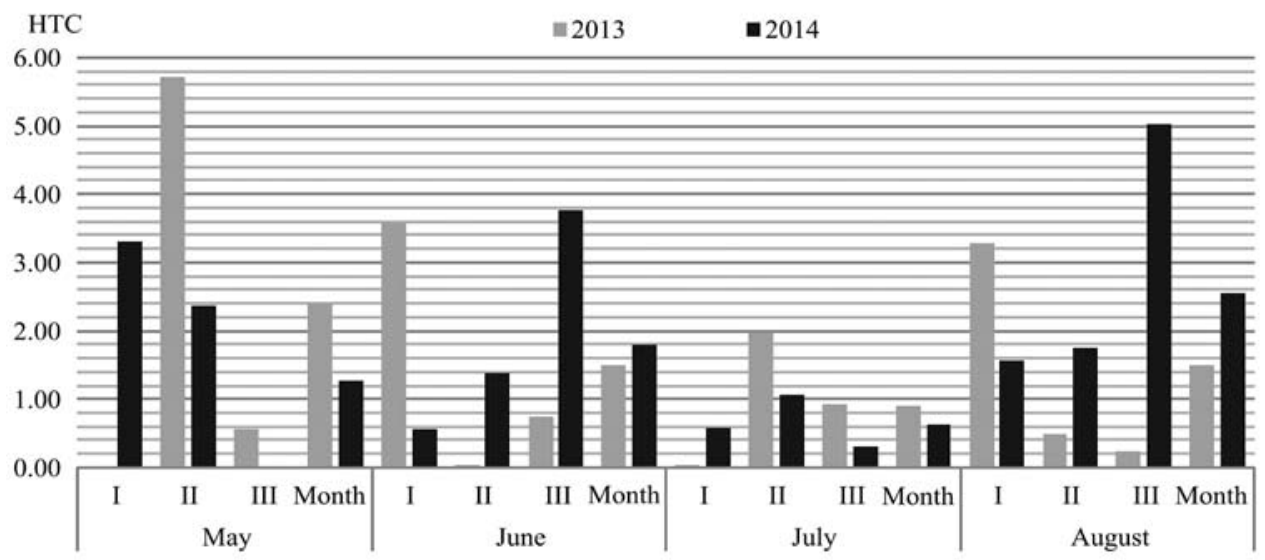

Figure. Hydrothermal coefficient (HTC) during plant vegetation period (Elmininkai Meteorological Station, 20132014)

the plants germinated well; however, during the third ten day period in May and the first ten day period in June the mean daily temperature was $5.4^{\circ} \mathrm{C}$ and $2.5^{\circ} \mathrm{C}$ higher compared with the multiannual average, but the rainfall was very low, thus the barley tillering was poor. During the period from the beginning of May to the middle of August, when the crop was harvested, the sum of active temperatures amounted to $1869.8^{\circ} \mathrm{C}$ and the rainfall was $233.1 \mathrm{~mm}$. Therefore, during June-August period the weather was favourable for spring barley growth and grain development.

Soil. The experiment was conducted on Bathihypogleyi-Haplic Luvisol (LVh-gld-w), soil texture - sandy loam with sandy clay loam in deeper layers, soil $\mathrm{pH}_{\mathrm{KCl}}-4.9-5.2$, organic carbon content $-1.04-1.57 \%$, plant available phosphorus $\left(\mathrm{P}_{2} \mathrm{O}_{5}\right)-193-237 \mathrm{mg} \mathrm{kg}^{-1}$ and potassium $\left(\mathrm{K}_{2} \mathrm{O}\right)$ content $-137-192 \mathrm{mg} \mathrm{kg}^{-1}$. Heavy metal concentration was as follows: cadmium $(\mathrm{Cd})-0.057$ $0.096 \mathrm{mg} \mathrm{kg}^{-1}$, lead $(\mathrm{Pb})-6.87-8.90 \mathrm{mg} \mathrm{kg}^{-1}$, nickel $(\mathrm{Ni})$ - 9.67-13.1 mg kg-1, copper $(\mathrm{Cu})-3.93-6.43 \mathrm{mg} \mathrm{kg}^{-1}$, zinc $(\mathrm{Zn})-22.0-30 \mathrm{mg} \mathrm{kg}^{-1}$ and manganese $(\mathrm{Mn})-46-$ $73 \mathrm{mg} \mathrm{kg}{ }^{-1}$.

Statistical analysis. Winter wheat and spring barley yield data was processed using the analysis of variance $A N O V A$. Statistical significance of the experimental data was assessed using Duncan's test; significant differences were established between the data lettered a, b, c, d, e, f at 5\% probability level $(P \leq 0.05)$ (Tarakanovas, Raudonius, 2003). Compost and yield chemical composition data was presented as arithmetical means with standard deviations using software MS Excel 2007.

\section{Results and discussion}

Chemical composition of composts of different origin. Composts used in the experiment varied in their quality (Table 1). The richest in nitrogen and phosphorus was biogas production waste compost followed by cattle manure compost; however, the latter also contained high amounts of potassium accounting for approximately 10 times higher content compared with green waste and sewage sludge composts, and nearly 5 times higher content compared with biogas production waste compost. Cattle manure and biogas production waste composts had high amounts of organic matter, the content of which exceeded $80 \%$, but very low amounts of dry matter $-15.1-24.5 \%$. Green waste compost had the lowest content of nitrogen, phosphorus and organic matter.

The lowest amounts of heavy metals were established in cattle manure and green waste composts (Table 1). In comparison, biogas production waste compost had $\mathrm{Cd}, \mathrm{Ni}, \mathrm{Zn}$ and $\mathrm{Cu}$ amounts which were 1.5-2.5 times higher. Meanwhile, sewage sludge compost had much higher heavy metal content compared with other composts, especially those of $\mathrm{Cd}, \mathrm{Ni}, \mathrm{Pb}$ and $\mathrm{Cu}$. Two of the elements $-\mathrm{Cd}$ and $\mathrm{Cu}-$ even exceeded the recommended permissible concentration for class I 
Table 1. Chemical composition of composts used in the experiment

\begin{tabular}{|c|c|c|c|c|}
\hline Indicators & $\begin{array}{c}\text { Cattle manure } \\
\text { compost }\end{array}$ & $\begin{array}{c}\text { Green waste } \\
\text { compost }\end{array}$ & $\begin{array}{c}\text { Biogas production } \\
\text { waste compost }\end{array}$ & $\begin{array}{c}\text { Sewage sludge } \\
\text { compost }\end{array}$ \\
\hline Dry matter \% & $15.1 \pm 3.6^{*}$ & $56.5 \pm 1.2$ & $24.5 \pm 3.1$ & $56.8 \pm 0.7$ \\
\hline $\mathrm{pH}_{\mathrm{H} 2 \mathrm{O}}$ & $8.4 \pm 0.4$ & $7.7 \pm 0.1$ & $8.1 \pm 0.2$ & $7.1 \pm 0.1$ \\
\hline \multicolumn{5}{|c|}{ of dry matter } \\
\hline Total nitrogen $(\mathrm{N}) \%$ & $2.5 \pm 0.4$ & $1.3 \pm 0.1$ & $4.2 \pm 0.5$ & $1.9 \pm 0.3$ \\
\hline Total phosphorus (P) \% & $0.85 \pm 1.2$ & $0.1 \pm 0.1$ & $1.9 \pm 0.0$ & $0.7 \pm 0.1$ \\
\hline Total potassium (K) \% & $2.74 \pm 1.2$ & $0.3 \pm 0.1$ & $0.6 \pm 0.1$ & $0.3 \pm 0.0$ \\
\hline Organic matter \% & $80.0 \pm 6.5$ & $23.3 \pm 0.6$ & $84.8 \pm 2.4$ & $34.7 \pm 1.5$ \\
\hline $\mathrm{Cd} \mathrm{mg} \mathrm{kg}^{-1}$ & $0.1 \pm 0.1$ & $0.1 \pm 0.0$ & $0.3 \pm 0.0$ & $0.9 \pm 0.1$ \\
\hline $\mathrm{Ni} \mathrm{mg} \mathrm{kg}{ }^{-1}$ & $2.4 \pm 1.5$ & $5.5 \pm 0.4$ & $13.6 \pm 0.2$ & $15.8 \pm 2.7$ \\
\hline $\mathrm{Pb} \mathrm{mg} \mathrm{kg}{ }^{-1}$ & $3.6 \pm 1.6$ & $13.1 \pm 0.6$ & $2.5 \pm 0.0$ & $24.8 \pm 5.4$ \\
\hline $\mathrm{Zn} \mathrm{mg} \mathrm{kg-1}$ & $138.7 \pm 102.2$ & $91.9 \pm 14.4$ & $238.3 \pm 10.0$ & $367.5 \pm 68.6$ \\
\hline $\mathrm{Cu} \mathrm{mg} \mathrm{kg}$ & $25.2 \pm 3.9$ & $18.1 \pm 3.0$ & $40.3 \pm 0.4$ & $94.0 \pm 14.1$ \\
\hline Mn mg kg-1 & $328.0 \pm 0.0$ & $223.0 \pm 19.8$ & $225.0 \pm 90.5$ & $411.0 \pm 128.7$ \\
\hline
\end{tabular}

* - means \pm standard deviation

composts in Lithuania, which accounts for $\leq 0.7$ and $\leq 70 \mathrm{mg} \mathrm{kg}^{-1}$ (Staugaitis et al., $2015 \mathrm{~b}$ ).

A total of $170 \mathrm{~kg} \mathrm{ha}^{-1}$ of $\mathrm{N}$ were applied with all types of composts, therefore, the amounts of composts applied varied as follows: green waste compost $-23.7 \mathrm{t} \mathrm{ha}^{-1}$, sewage sludge compost $-15.5 \mathrm{t} \mathrm{ha}^{-1}$, biogas production waste compost $-16.5 \mathrm{t} \mathrm{ha}^{-1}$ and cattle manure compost - $44.5 \mathrm{t} \mathrm{ha}^{-1}$. These composts brought in different amounts of the most important macroelements and heavy metals (Table 2). Phosphorus $\left(\mathrm{P}_{2} \mathrm{O}_{5}\right)$ amount

brought in with green waste compost was $43 \mathrm{~kg} \mathrm{ha}^{-1}$, whereas 2.7-4.0 times higher amounts were brought in with other composts. High amounts of potassium $\left(\mathrm{K}_{2} \mathrm{O}\right)$ were brought in with cattle manure compost - actually $221 \mathrm{~kg} \mathrm{ha}^{-1}$, whereas $31-53 \mathrm{~kg} \mathrm{ha}^{-1}$ with other composts. Sewage sludge compost brought in exceptionally high amounts of heavy metals and the differences from other types of composts ranged from several to several tens of times lower.

Table 2. Amounts of organic matter, phosphorus, potassium and heavy metals incorporated in soil together with composts

\begin{tabular}{cccccc}
\hline & Unit & \multicolumn{3}{c}{ Composts } \\
\cline { 3 - 6 } Indicators & $\begin{array}{c}\text { cattle manure } \\
\text { compost }\end{array}$ & $\begin{array}{c}\text { green waste } \\
\text { compost }\end{array}$ & $\begin{array}{c}\text { biogas production } \\
\text { waste compost }\end{array}$ & $\begin{array}{c}\text { sewage sludge } \\
\text { compost }\end{array}$ \\
\hline Organic matter & $\mathrm{t} \mathrm{ha}^{-1}$ & 5.37 & 3.11 & 3.44 & 3.06 \\
$\mathrm{Pg} \mathrm{ha}_{2} \mathrm{O}_{5}$ & 131 & 43 & 175 & 137 \\
$\mathrm{~K}_{2} \mathrm{~kg}^{-1}$ & & 221 & 53 & 31 & 31 \\
$\mathrm{Cd}$ & $\mathrm{g} \mathrm{ha}^{-1}$ & 0.4 & 1.6 & 1.0 & 7.9 \\
$\mathrm{Ni}$ & & 10 & 73 & 55 & 218 \\
$\mathrm{~Pb}$ & & 19 & 175 & 963 & 3233 \\
$\mathrm{Zn}$ & & 493 & 1230 & 163 & 827 \\
$\mathrm{Cu}$ & 207 & 242 & 910 & 3616 \\
$\mathrm{Mn}$ & & 2109 & 2986 & & \\
\hline
\end{tabular}

Influence of composts on yield of winter wheat and spring barley. The influence of different composts on the grain and straw yield of winter wheat and spring barley varied (Table 3). During the first year after compost incorporation winter wheat was cultivated. Grain and straw yield did not increase statistically significantly in the treatments not fertilized with mineral fertilizers; however, during the second year all composts applied increased spring barley yield.

As a result of compost effect, barley grain yield increased as follows: affected by biogas production waste $-72.9 \%$, green waste $-68.6 \%$, cattle manure $58.9 \%$ and sewage sludge $-45.2 \%$; straw yield increased by $39.9,36.8,36.3$ and $52.3 \%$, respectively. Mineral fertilizers increased the winter wheat yield by $29.5 \%$ and that of spring barley next year - by $47.8 \%$ compared with without fertilizers application. The application of composts against the background of mineral fertilizers did not statistically significantly increase winter wheat and spring barley yields with the only exception of cattle manure compost incorporated for winter wheat, when grain yield increase achieved was $18.3 \%$ higher compared with mere mineral fertilizer application.
The experimental results indicated that the influence of composts was not significant against the background of mineral fertilizers, and without mineral fertilizers the effect was manifested only on the barley cultivated during the second year, which was especially prominent with biogas production waste and green waste composts applications. This is somewhat contradictory to the data by other researches suggesting that compost effect on plant productivity is higher compared with mineral fertilizers (Bulluck et al., 2002) or, that plant productivity does not differ significantly between compost of mineral fertilizer applications (Eghball, Power, 1999). However, the experimental results achieved prove the provision that combined use of both composts and mineral fertilizers increases their overall efficiency, which in its turn increases crop productivity (Keeling et al., 2003).

Chemical composition of plant yield. Concentrations of total nitrogen, phosphorus and potassium in the grain and straw of winter wheat and spring barley are indicated in Table 4, where compost influence was investigated against the background without mineral fertilizers, i.e. plots of treatments 1-5. 
Table 3. Winter wheat and spring barley yield $\left(\mathrm{t} \mathrm{ha}^{-1}\right)$ as affected by different kinds of composts

\begin{tabular}{lcccc}
\hline \multirow{2}{*}{ Fertilization } & & \multicolumn{2}{c}{ Grain yield } & \multicolumn{2}{c}{ Straw yield } \\
\cline { 2 - 5 } & winter wheat & spring barley & winter wheat & spring barley \\
\hline Without fertilizers & $3.39 \mathrm{a}$ & $2.99 \mathrm{a}$ & $2.28 \mathrm{ab}$ & $1.93 \mathrm{a}$ \\
Cattle manure compost & $3.64 \mathrm{a}$ & $4.75 \mathrm{bcde}$ & $2.25 \mathrm{ab}$ & $2.63 \mathrm{~b}$ \\
Green waste compost & $3.67 \mathrm{a}$ & $5.04 \mathrm{cde}$ & $2.64 \mathrm{~b}$ & $2.64 \mathrm{~b}$ \\
Biogas production waste compost & $3.45 \mathrm{a}$ & $5.17 \mathrm{e}$ & $2.50 \mathrm{ab}$ & $2.70 \mathrm{bc}$ \\
Sewage sludge compost & $3.51 \mathrm{a}$ & $4.34 \mathrm{~b}$ & $1.99 \mathrm{a}$ & $2.94 \mathrm{bcd}$ \\
Mineral fertilizer & $4.93 \mathrm{~b}$ & $4.42 \mathrm{bc}$ & $3.36 \mathrm{~cd}$ & $3.27 \mathrm{cdef}$ \\
Cattle manure compost + mineral fertilizer & $5.83 \mathrm{~d}$ & $5.01 \mathrm{cde}$ & $3.77 \mathrm{~d}$ & $3.77 \mathrm{f}$ \\
Green waste compost + mineral fertilizer & $5.05 \mathrm{bcd}$ & $4.90 \mathrm{bcde}$ & $3.44 \mathrm{~cd}$ & $3.11 \mathrm{bcd}$ \\
Biogas production waste compost + mineral fertilizer & $4.96 \mathrm{~b}$ & $4.90 \mathrm{bcde}$ & $3.38 \mathrm{~cd}$ & $2.93 \mathrm{bcd}$ \\
Sewage sludge compost + mineral fertilizer & $4.90 \mathrm{~b}$ & $4.45 \mathrm{bc}$ & $3.38 \mathrm{~cd}$ & $3.33 \mathrm{dfe}$ \\
\hline
\end{tabular}

Note. The difference between the values with the same letter was not statistically significant between the various fertilization at $p \leq 0.05$ according to Duncan's test.

Table 4. Nitrogen (N), phosphorus (P) and potassium (K) concentrations (\%) in winter wheat and spring barley grain and straw

\begin{tabular}{|c|c|c|c|c|c|c|}
\hline \multirow{3}{*}{ Fertilization } & $\mathrm{N}$ & $\mathrm{P}$ & $\mathrm{K}$ & $\mathrm{N}$ & $\mathrm{P}$ & $\mathrm{K}$ \\
\hline & \multicolumn{6}{|c|}{ of dry matter } \\
\hline & \multicolumn{3}{|c|}{ winter wheat } & \multicolumn{3}{|c|}{ wpring barley } \\
\hline \multicolumn{7}{|c|}{ Grain } \\
\hline Without fertilizers & $2.11 \pm 0.03$ & $0.42 \pm 0.01$ & $0.36 \pm 0.01$ & $2.08 \pm 0.03$ & $0.50 \pm 0.02$ & $0.55 \pm 0.00$ \\
\hline Cattle manure compost & $2.11 \pm 0.01$ & $0.44 \pm 0.04$ & $0.40 \pm 0.06$ & $2.11 \pm 0.08$ & $0.52 \pm 0.02$ & $0.54 \pm 0.01$ \\
\hline Green waste compost & $2.16 \pm 0.08$ & $0.43 \pm 0.01$ & $0.39 \pm 0.01$ & $2.24 \pm 0.11$ & $0.53 \pm 0.00$ & $0.58 \pm 0.01$ \\
\hline Biogas production waste compost & $2.21 \pm 0.04$ & $0.46 \pm 0.04$ & $0.39 \pm 0.02$ & $2.09 \pm 0.01$ & $0.52 \pm 0.02$ & $0.55 \pm 0.01$ \\
\hline Sewage sludge compost & $2.18 \pm 0.09$ & $0.44 \pm 0.02$ & $0.39 \pm 0.02$ & $2.35 \pm 0.12$ & $0.52 \pm 0.01$ & $0.57 \pm 0.03$ \\
\hline \multicolumn{7}{|c|}{ Straw } \\
\hline Without fertilizers & $0.39 \pm 0.04$ & $0.13 \pm 0.00$ & $0.51 \pm 0.01$ & $0.74 \pm 0.03$ & $0.09 \pm 0.04$ & $0.51 \pm 0.01$ \\
\hline Cattle manure compost & $0.48 \pm 0.10$ & $0.17 \pm 0.03$ & $0.63 \pm 0.00$ & $0.94 \pm 0.07$ & $0.15 \pm 0.06$ & $0.83 \pm 0.18$ \\
\hline Green waste compost & $0.37 \pm 0.09$ & $0.15 \pm 0.01$ & $0.53 \pm 0.07$ & $0.78 \pm 0.12$ & $0.11 \pm 0.00$ & $0.55 \pm 0.06$ \\
\hline Biogas production waste compost & $0.40 \pm 0.04$ & $0.16 \pm 0.01$ & $0.64 \pm 0.01$ & $0.83 \pm 0.04$ & $0.12 \pm 0.03$ & $0.62 \pm 0.01$ \\
\hline Sewage sludge compost & $0.42 \pm 0.10$ & $0.17 \pm 0.01$ & $0.65 \pm 0.01$ & $0.63 \pm 0.02$ & $0.11 \pm 0.01$ & $0.62 \pm 0.03$ \\
\hline
\end{tabular}

Comparison with the untreated treatment revealed that the nitrogen concentration in winter wheat grain was increased marginally $(0.10 \%)$ by fertilization with biogas production waste compost, but there was no regular compost influence on nitrogen variation in straw established. Meanwhile, nitrogen concentration increase in spring barley grain was more prominent: fertilization with sewage sludge and green waste composts resulted in $0.27 \%$ and $0.16 \%$ increase.

Nitrogen concentration in the straw of barley fertilized with cattle manure compost was $0.20 \%$ higher; however, it decreased by $0.11 \%$ when fertilized with sewage sludge compost. It indicates that nitrogen concentration variations in plants are more prominent during the second year after fertilization. Nitrogen concentration in plants varied due to unequal amounts of organic matter incorporated with composts and its different mineralization.

Types of compost did not have any significant influence on phosphorus concentration in the grain of winter wheat and spring barley. Such influence was not established in spring barley straw either. Phosphorus concentrations in winter wheat straw ranged within a short interval $0.02-0.04 \%$.

In the experiment, potassium concentration in winter wheat grain ranged within a short interval 0.03 $0.04 \%$, whereas in straw potassium content ranged from $0.12 \%$ to $0.14 \%$ due to cattle manure, biogas production waste and sewage sludge composts influence. During the second experimental year while cultivating spring barley, potassium concentration in grain was $0.03 \%$ higher, when fertilizing with green waste compost, and in straw it was
$0.11 \%$ higher in the case of biogas production waste, sewage sludge and especially cattle manure compost fertilization, where potassium concentration increased by $0.32 \%$. This was influenced by the actual amount of $221 \mathrm{~kg} \mathrm{ha}^{-1} \mathrm{~K}_{2} \mathrm{O}$ brought in the soil together with this compost. The fluctuations of potassium content in straw were much higher compared with grain due to compost fertilization.

Content of heavy metals in grain and straw. The influence of different composts on the content of heavy metals in winter wheat and spring barley grain is presented in Tables 5 and 6 .

$\mathrm{Cu}, \mathrm{Zn}$ and $\mathrm{Mn}$ play an important role as microelements in plant nutrition; however, higher concentrations of these chemical elements accumulated in soil can have a negative impact on plants. The optimal $\mathrm{Cu}$ concentration in the dry matter of the above-ground part of winter wheat at stages $\mathrm{BBCH} 30-31$ is 7-15, and that for spring barley is $6-12 \mathrm{mg} \mathrm{kg}^{-1}$ (Bergmann, 1986). Later this content decreases and at stages BBCH 42-45 it is $3.5-8.8$ and $3.7-13.0 \mathrm{mg} \mathrm{kg}^{-1}$, respectively (Breuer et al., 2003). Its content in the grain cultivated in Lithuania is approximately $4.09 \mathrm{mg} \mathrm{kg}^{-1}$ on average (Lubyte et al., 2001). In our experiments, $\mathrm{Cu}$ concentration in winter wheat grain ranged from 3.53 to $4.18 \mathrm{mg} \mathrm{kg}^{-1}$, and in straw it was $1.89-2.29 \mathrm{mg} \mathrm{kg}^{-1}$; in spring barley it was $4.10-5.65$ and $1.81-2.07 \mathrm{mg} \mathrm{kg}^{-1}$, respectively.

Somewhat higher $\mathrm{Cu}$ concentrations were established in winter wheat and spring barley grain only after fertilizing them with green waste compost. Meanwhile, other types of composts did not have any influence on $\mathrm{Cu}$ concentrations both in winter wheat 
Table 5. Concentrations of heavy metals in winter wheat grain and straw as affected by the application of different kinds of composts

\begin{tabular}{lcccccc}
\hline \multirow{2}{*}{\multicolumn{1}{c}{ Fertilization }} & $\mathrm{Cu}$ & $\mathrm{Zn}$ & $\mathrm{Mn}$ & $\mathrm{Pb}$ & $\mathrm{Cd}$ & $\mathrm{Ni}$ \\
\cline { 2 - 7 } & \multicolumn{7}{c}{$\mathrm{mg} \mathrm{kg}^{-1}$ of dry matter } \\
\hline Without fertilizers & $3.53 \pm 0.52$ & $22.82 \pm 0.03$ & $49.89 \pm 0.21$ & $0.056 \pm 0.030$ & $0.045 \pm 0.003$ & $0.359 \pm 0.091$ \\
Green waste compost & $4.18 \pm 0.36$ & $23.55 \pm 0.92$ & $51.05 \pm 4.53$ & $0.055 \pm 0.030$ & $0.051 \pm 0.007$ & $0.414 \pm 0.095$ \\
Biogas production waste compost & $3.55 \pm 0.06$ & $22.03 \pm 0.25$ & $43.49 \pm 1.94$ & $0.049 \pm 0.004$ & $0.044 \pm 0.006$ & $0.470 \pm 0.028$ \\
Sewage sludge compost & $3.73 \pm 0.47$ & $23.10 \pm 0.71$ & $46.09 \pm 3.31$ & $0.071 \pm 0.018$ & $0.046 \pm 0.010$ & $0.402 \pm 0.002$ \\
\hline \multicolumn{7}{c}{ Straw } \\
Without fertilizers & $2.22 \pm 0.03$ & $5.28 \pm 0.28$ & $22.88 \pm 8.17$ & $0.045 \pm 0.006$ & $0.048 \pm 0.012$ & $0.420 \pm 0.147$ \\
Green waste compost & $2.29 \pm 1.15$ & $5.23 \pm 1.00$ & $23.35 \pm 8.41$ & $0.043 \pm 0.002$ & $0.050 \pm 0.011$ & $0.802 \pm 0.119$ \\
Biogas production waste compost & $1.89 \pm 0.52$ & $5.25 \pm 0.21$ & $30.12 \pm 6.15$ & $0.047 \pm 0.000$ & $0.041 \pm 0.001$ & $0.598 \pm 0.190$ \\
Sewage sludge compost & $1.90 \pm 0.53$ & $6.63 \pm 0.83$ & $28.54 \pm 1.44$ & $0.041 \pm 0.009$ & $0.050 \pm 0.004$ & $0.770 \pm 0.156$ \\
\hline
\end{tabular}

Table 6. Concentrations of heavy metals in spring barley grain and straw as affected by the application of different kinds of composts

\begin{tabular}{|c|c|c|c|c|c|c|}
\hline \multirow{2}{*}{ Fertilization } & $\mathrm{Cu}$ & $\mathrm{Zn}$ & $\mathrm{Mn}$ & $\mathrm{Pb}$ & $\mathrm{Cd}$ & $\mathrm{Ni}$ \\
\hline & \multicolumn{6}{|c|}{$\mathrm{mg} \mathrm{kg}^{-1}$ of dry matter } \\
\hline \multicolumn{7}{|c|}{ Grain } \\
\hline Without fertilizers & $4.10 \pm 0.20$ & $24.55 \pm 1.20$ & $14.15 \pm 7.32$ & $0.030 \pm 0.001$ & $0.016 \pm 0.002$ & $0.928 \pm 0.123$ \\
\hline Green waste compost & $5.65 \pm 1.03$ & $25.25 \pm 2.33$ & $20.27 \pm 0.45$ & $0.032 \pm 0.003$ & $0.020 \pm 0.000$ & $0.960 \pm 0.039$ \\
\hline Biogas production waste compost & $4.26 \pm 0.46$ & $23.40 \pm 0.42$ & $16.50 \pm 4.24$ & $0.027 \pm 0.001$ & $0.016 \pm 0.000$ & $1.248 \pm 0.230$ \\
\hline Sewage sludge compost & $4.76 \pm 0.15$ & $24.55 \pm 3.32$ & $11.95 \pm 2.73$ & $0.033 \pm 0.004$ & $0.015 \pm 0.002$ & $1.286 \pm 0.375$ \\
\hline \multicolumn{7}{|c|}{ Straw } \\
\hline Without fertilizers & $1.81 \pm 0.22$ & $6.83 \pm 0.37$ & $14.40 \pm 7.96$ & $0.062 \pm 0.010$ & $0.052 \pm 0.000$ & $0.188 \pm 0.013$ \\
\hline Green waste compost & $1.88 \pm 0.64$ & $6.28 \pm 0.26$ & $19.97 \pm 0.50$ & $0.066 \pm 0.016$ & $0.055 \pm 0.014$ & $0.214 \pm 0.003$ \\
\hline Biogas production waste compost & $2.07 \pm 0.28$ & $7.32 \pm 1.03$ & $16.25 \pm 4.21$ & $0.073 \pm 0.005$ & $0.044 \pm 0.004$ & $0.221 \pm 0.017$ \\
\hline Sewage sludge compost & $1.93 \pm 0.15$ & $6.69 \pm 0.08$ & $16.35 \pm 3.75$ & $0.081 \pm 0.040$ & $0.057 \pm 0.030$ & $0.206 \pm 0.048$ \\
\hline
\end{tabular}

and spring barley. According to different authors, the maximum $\mathrm{Cu}$ concentration in grain while fertilizing it with sewage sludge compost ranged from 11 to $23 \mathrm{mg}$ $\mathrm{kg}^{-1}$ (Hassan et al., 2013).

The optimal $\mathrm{Zn}$ concentration in the aboveground mass of many cereals is $25-70 \mathrm{mg} \mathrm{kg}^{-1}$ in the beginning of growth (Bergmann, 1986), and at stages $\mathrm{BBCH} 42-45$ it is $17-24$ and $14-60 \mathrm{mg} \mathrm{kg}^{-1}$ in winter wheat and spring barley, respectively (Breuer et al., 2003). Its content in the grain cultivated in Lithuania is $19 \pm 5.2 \mathrm{mg}$ $\mathrm{kg}^{-1}$ on average (Lubyte et al., 2001). In the experiments, $\mathrm{Zn}$ concentration in winter wheat grain and straw ranged within the limits - 22.03-23.55 and 5.23-6.63 $\mathrm{mg} \mathrm{kg}^{-1}$, respectively, and that in spring barley grain and straw was $23.40-25.25$ and $6.28-7.32 \mathrm{mg} \mathrm{kg}^{-1}$, respectively. We did not observe regular influence of composts on $\mathrm{Zn}$ concentration in the grain of winter wheat and spring barley. During the experiment, $\mathrm{Zn}$ concentrations in the cereals did not reach the ones achieved by the majority of researchers, and the maximum $\mathrm{Zn}$ concentrations observed in wheat grain by certain researchers were indicated to reach $133 \mathrm{mg} \mathrm{kg}^{-1}$ (Hassan et al., 2013).

The optimal Mn concentration in the aboveground mass of many cereals is $30-100 \mathrm{mg} \mathrm{kg}^{-1}$ (Bergmann, 1986). It was established that the average content of $\mathrm{Mn}$ in the grain cultivated in Lithuania is $16.1 \mathrm{mg} \mathrm{kg}^{-1}$ (Lubyte etal., 2001). In the experiment, Mn concentration in winter wheat grain and straw ranged from 43.49 to $51.05 \mathrm{mg} \mathrm{kg}^{-1}$ and from 22.88 to $30.12 \mathrm{mgkg}^{-1}$, respectively, and that in spring barley grain and straw was 11.95-20.27 and $14.40-19.97 \mathrm{mg} \mathrm{kg}^{-1}$. The composts used did not increase Mn concentration in plants; however, in grain it decreased, when fertilizing wheat with biogas production waste compost. Although the least content of Mn was incorporated with this compost, compared with other composts, other factors could have had influence such as the interaction between chemical elements, as the highest nitrogen concentration was established in grain as well. The Mn concentration in winter wheat grain determined in the experiment was marginally higher compared with those indicated by many other researchers, namely 18 $50 \mathrm{mg} \mathrm{kg}^{-1}$ (Karatas et al., 2006; Bermudez et al., 2011). The increase of $\mathrm{Pb}, \mathrm{Ca}$ and $\mathrm{Ni}$ concentrations in plant produce is undesirable (Lubyte et al., 2001), and in spring barley grain it should not exceed the maximum permissible concentration of $0.1 \mathrm{mg} \mathrm{kg}^{-1}$ and winter wheat $0.2 \mathrm{mg} \mathrm{kg}^{-1}$ in the case of $\mathrm{Cd}$ and $0.2 \mathrm{mg} \mathrm{kg}^{-1}$ of $\mathrm{Pb}$ according to European Commission Regulations Nos. 1881/2006 (http://eur-lex.europa.eu/eli/reg/2006/1881/ oj) and 629/2008 (http://eur-lex.europa.eu/eli/ $\mathrm{reg} / 2008 / 629 / \mathrm{oj})$.

$\mathrm{Pb}$ concentration in winter wheat grain was established to be higher and varied more substantially compared with spring barley. In winter wheat grain it ranged from 0.049 to $0.071 \mathrm{mg} \mathrm{kg}^{-1}$, and in spring barley it was $0.027-0.033 \mathrm{mg} \mathrm{kg}^{-1}$. The analysed composts did not increase $\mathrm{Pb}$ concentrations either in straw or grain of both crops. The concentration determined was marginal compared with the permissible $0.2 \mathrm{mg} \mathrm{kg}^{-1}$ limit or the one indicated by other authors and related with environmental pollution - 8-22 $\mathrm{mg} \mathrm{kg}^{-1}$ (Jamali et al., 2009).

$\mathrm{Cd}$ concentration in winter wheat grain and straw was similar and ranged between $0.041-0.051 \mathrm{mg}$ $\mathrm{kg}^{-1}$, and in spring barley grain it was lower $-0.015-$ $0.020 \mathrm{mg} \mathrm{kg}^{-1}$. In both crops, irrespective of the compost type applied, $\mathrm{Cd}$ concentration was mainly within the margin of error and was low compared with the ones established by other authors for grain $\left(0.8-1.18 \mathrm{mg} \mathrm{kg}^{-1}\right)$, when wheat was fertilized with sewage sludge compost (Karak, Bhattacharyya, 2010; Hassan et al., 2013).

$\mathrm{Ni}$ concentration in winter wheat and spring barley varied within a broad range: $0.359-1.289 \mathrm{mg} \mathrm{kg}^{-1}$ in grain and $0.188-0.802 \mathrm{mg} \mathrm{kg}^{-1}$ in straw. A higher Ni concentration in winter wheat grain was obtained while 
fertilizing with biogas production waste, and in straw by green waste and sewage sludge composts, whereas in spring barley grain - by biogas production waste compost, and in straw - by green waste and biogas production waste composts. This indicates that the Ni amount of 55-139 $\mathrm{g} \mathrm{ha}^{-1}$ incorporated in soil with composts had influence on its concentration in the crop for two years after the incorporation. $\mathrm{Ni}$ increases obtained in the crops were not high compared with other researchers' data, where the established Ni concentration in wheat grain amounted to $4.1-9.9 \mathrm{mg} \mathrm{kg}^{-1}$ (Hassan et al., 2013).

\section{Conclusions}

1. The richest in nitrogen $(\mathrm{N})$ and phosphorus $(\mathrm{P})$ was biogas production waste compost followed by cattle manure compost; however, the latter also contained high amounts of potassium $(\mathrm{K})$ accounting for approximately 10 times higher content compared with green waste and sewage sludge composts, and nearly 5 times higher content compared with biogas production waste compost. Cattle manure and biogas production waste composts had high amounts of organic matter, the content of which exceeded $80 \%$, but very low amounts of dry matter $-15.1-24.5 \%$. Green waste compost had the lowest content of N, P and organic matter. The lowest amounts of heavy metals were established in cattle manure and green waste composts. In comparison, biogas production waste compost had $\mathrm{Cd}$, $\mathrm{Ni}, \mathrm{Zn}$ and $\mathrm{Cu}$ amounts which were 1.5-2.5 times higher. Meanwhile, sewage sludge compost had much higher heavy metal content compared with other composts, especially those of $\mathrm{Cd}, \mathrm{Ni}, \mathrm{Pb}$ and $\mathrm{Cu}$.

2 . The composts incorporated without mineral fertilizer did not increase the yield of winter wheat in the first year after incorporation. During the second year, the composts increased the spring barley crop as follows: biogas production waste - by $72.9 \%$, green waste $68.6 \%$, cattle manure $-58.9 \%$ and sewage sludge $45.2 \%$; straw yield increased by $39.9,36.8,36.3$ and 52.3 $\%$, respectively. The application of composts against the background of mineral fertilizers, which was $\mathrm{N}_{90} \mathrm{P}_{60} \mathrm{~K}_{90}$ for winter wheat and $\mathrm{N}_{60} \mathrm{P}_{40} \mathrm{~K}_{60}$ for spring barley, did not significantly increase winter wheat and spring barley grain and straw yields compared with mineral fertilizers.

3 . The concentration of chemical elements in grain and straw depended on the compost degradation process in soil. During the first year, N concentration in winter wheat grain was increased by biogas production waste compost, and during the second year - by sewage sludge and green waste composts in spring barley grain. $\mathrm{K}$ concentration in winter wheat and spring barley straw was increased by cattle manure, biogas production waste and sewage sludge composts, and $\mathrm{N}$ concentration in spring barley straw was increased by cattle manure compost. During the first year all composts increased $P$ concentration in winter wheat straw; however, during the second year such tendency was not observed in spring barley straw. Heavy metal $(\mathrm{Cd}, \mathrm{Ni}, \mathrm{Pb}, \mathrm{Zn}, \mathrm{Mn}$ and $\mathrm{Cu}$ ) concentrations in plants were close to the background levels.

4. Heavy metal $(\mathrm{Cd}, \mathrm{Ni}, \mathrm{Pb}, \mathrm{Zn}, \mathrm{Mn}$ and $\mathrm{Cu})$ concentrations in grain and straw were close to the background levels. The composts used in winter wheat and spring barley increased the content of $\mathrm{Ni}$ somewhat more significantly, especially in spring barley grain when biogas production waste and sewage sludge composts fertilization increased the content of this element by 0.32 and $0.36 \mathrm{mg} \mathrm{kg}^{-1}$.

Received 17062016 Accepted 06102016

\section{References}

Bergmann W. 1986. Nutritional dysfunction in crops. Formation, visual and analytical diagnosis. Jena, Germany, p. 166-178 (in German)

Bermudez G. M., Jasan S., Pla R., Pignata M. L. 2011. Heavy metal and trace element concentrations in wheat grains: assessment of potential non-carcinogenic health hazard through their consumption. Journal of Hazardous Materials. 193: 264-271 http://dx.doi.org/10.1016/j.jhazmat.2011.07.058

Breuer J., König V., Merkel D., Olfs H. W., Steingrobe B., Stimpfl E., Wissemeier A., Zorn W. 2003. Plant analysis for the diagnosis of the nutritional status of crops. Agrimedia, p. 33-34 (in German)

Bulluck L. R., Brosius M., Evanylo G. K., Ristaino J. B. 2002. Organic and synthetic fertility amendments influence soil microbial, physical and chemical properties on organic and conventional farms. Annlied Soil Ecologv, 19 (2): 147-160 http://dx.doi.org/10.1016/S0929-1393(01)00187-1

Carvalho E., Marchi S. 2015. Lettuce growth characteristics as affected by fertilizers, liming, and a soil conditioner. Journal of Horticulture and Forestry, 7 (3): 65-72 http://dx.doi.org/10.5897/JHF2015.0386

Dirsė A., Taparauskienè L. 2010. Humidity fluctuations in plant vegetation periods and a comparison of its assessment methods. Zemès ūkio mokslai, 17 (1-2): 9-17 (in Lithuanian)

Eghball B., Power J. F. 1999. Composted and noncomposted manure application to conventional and notillage systems: corn yield and nitrogen uptake. Agronomy Journal. 91: 819-825 http://dx.doi.org/10.2134/agronj1999.915819x

Fuchs J. G., Berner A., Jochen M., Smidt E., Schleiss K. 2008. Influence of compost and digestates on plant growth and health: potentials and limits. The International Congress CODIS: compost and digestate: sustainability, benefits, impacts for the environment and for plant production. Solothurn, Switzerland, p. 101-110

Greger M., Malm T., Kautsky L. 2007. Heavy metal transfer from composted macroalgae to crops. European Journal of Agronomy, 26 (3): 257-265

http://dx.doi.org/10.1016/j.eja.2006.10.003

Hassan U. N., Mahmood Q., Waseem A., Irshad M., Faridullah F., Pervez A. 2013. Assessment of heavy metals in wheat plants irrigated with contaminated wastewater. Polish Journal of Environmental Studies, 22 (1): 115-123

Jamali M. K., Kazi T. G., Arain M. B., Afridi H. I., Jalbani N., Kandhro G. A., Shah A. Q., Baig J. A. 2009. Heavy metal accumulation in different varieties of wheat (Triticum aestivum $\mathrm{L}$.) grown in soil amended with domestic sewage sludge. Journal of Hazardous Materials. 164 (2-3): 13861391 http://dx.doi.org/10.1016/j.jhazmat.2008.09.056

Karak T., Bhattacharyya P. 2010. Heavy metal accumulation in soil amended with roadside pond sediment and uptake by winter wheat (Triticum aestivum L. cv. PBW 343). The Scientific World Journal. 10: 2314-2329 http://dx.doi.org/10.1100/tsw.2010.220

Karatas M., Dursun S., Guler E., Ozdemir C., Argun M. E. 2006. Heavy metal accumulation in wheat plants irrigated by waste water. Cellulose Chemistry and Technology, 40 (7): 575-579

Keeling A. A., McCallum K. R., Beckwith C. P. 2003. Mature green waste compost enhances growth and nitrogen uptake in wheat (Triticum aestivum L.) and oilseed rape (Brassica napus L.) through the action of water-extractable factors. Bioresource Technology. 90 (2): 127-132 http://dx.doi.org/10.1016/S0960-8524(03)00125-1

Kirkham M. B. 2006. Cadmium in plants on polluted soils: effects of soil factors, hyperaccumulation, and amendments. Geoderma. 137: 19-32

http://dx.doi.org/10.1016/j.geoderma.2006.08.024

Larney F. J., Olson A. F., Miller J. J., DeMaere P. R., Zvomuya F., McAllister T. A. 2008. Physical and chemical changes during composting of wood chip-bedded and straw-bedded beef cattle feedlot manure. Journal of Environmental Ouality. 37: 725-735 http://dx.doi.org/10.2134/jeq2007.0351 
Lubytė J., Antanaitis A., Matusevičius K., Mažvila J. 2001. Heavy metals in agricultural crops and their production. Heavy metals in Lithuanian soils and plants, p. 143-152 (in Lithuanian)

McLaughlin M. J., Parker D. R., Clarke J. M. 1999. Metals and micronutrients - food safety issues. Field Crops Research, 60: $143-163$ http://dx.doi.org/10.1016/S0378-4290(98)00137-3

Moral R., Paredes C., Bustamante M. A., Marhuenda-Egea F., Bernal M. P. 2009. Utilisation of manure composts by high-value crops: Safety and environmental challenges. Bioresource Technologv. 100 (22): 5454-5460 http://dx.doi.org/10.1016/j.biortech.2008.12.007

Natal-da-Luz T., Tidona S., Jesus B., Morais P. V., Sousa J. P. 2009. The use of sewage sludge as soil amendment. The need for an ecotoxicological evaluation. Journal of Soils Sediments. 9 (3): 246-260 http://dx.doi.org/10.1007/s11368-009-0077-x

Navas A., Lindhotfer H. 2005. Chemical partitioning of Fe, Mn, Zn and $\mathrm{Cr}$ in mountain soils of the Iberia and Pyrenean Ranges (NE Spain). Soil and Sediment Contamination. 14 (3): 249 260 http://dx.doi.org/10.1080/15320380590928311

Paradelo R., Moldes A. B., Rodríguez M., Barral M. T. 2008. Relationship between heavy metals and phytotoxicity compost. Ciencia y Tecnología Alimentaria. 6 (2): 143151 http://dx.doi.org/10.1080/11358120809487639
Staugaitis G., Gvildienė K., Mažeika R. 2015 (a). Influence of composts of various origins on leaf lettuce and soil properties. Žemès ūkio mokslai-Agricultural Sciences, 22 (3): 150-151 (in Lithuanian)

Staugaitis G., Mažeika R., Gvildienė K., Narutytė I. 2015 (b). Assessment of compost materials and quality. Innovative solutions of soil and agrochemistry science, p. 256-267, 306 (in Lithuanian)

Tarakanovas P., Raudonius S. 2003. Agronominių tyrimų duomenu staitistinè analizè taikant kompiuterines programas ANOVA, STAT, SPLIT-PLOT iš paketo SELEKCIJA ir IRRISTAT. Lithuanian University of Agriculture, 58 p. (in Lithuanian)

Tooba H., Tasneem A. A., Razia B. 2014. Seed germination bioassay using maize seeds for phytoxicity evaluation of different composted materials. Pakistan Journal of Botany, 46 (2): 539-542

Uriah L. A., Shehu U. 2014. Environmental risk assessment of heavy metals content of municipal solid waste used as organic fertilizer in vegetable gardens on the Jos Plateau, Nigeria. American Journal of Environmental Protection, 3 (6): $1-13$

Zheljazkov V. D., Warman P. R. 2004. Phytoavailability and fractionation of copper, manganese, and zinc in soil following application of two composts to four crops. Environmental Pollution. 131 (2): 187-195 http://dx.doi.org/10.1016/j.envpol.2004.02.007

ISSN 1392-3196 / e-ISSN 2335-8947

Zemdirbyste-Agriculture, vol. 103, No. 4 (2016), p. 355-362

DOI 10.13080/z-a.2016.103.045

\title{
Kompostų ịtaka žieminiụ kviečių bei vasarinių miežių derliui ir cheminių elementų kiekiui
}

\author{
G. Staugaitis ${ }^{1}$, I. Narutyte ${ }^{1}$, J. Arbačauskas ${ }^{1}$, Z. Vaišvila ${ }^{1}$, K. Rainys ${ }^{2}$, R. Mažeika ${ }^{1}$, \\ A. Masevičienè $\dot{1}^{1}$ L. Žičkiené ${ }^{1}$, D. Šumskis ${ }^{1}$
}

${ }^{1}$ Lietuvos agrarinių ir miškų mokslų centro Agrocheminių tyrimų laboratorija

${ }^{2}$ Lietuvos agrarinių ir miškų mokslų centro Elmininkų bandymų stotis

\section{Santrauka}

2013-2014 m. giliau glèjiškame paprastajame išplautžemyje, kuriame vyravo smèlingas priemolis, o $\mathrm{pH}_{\mathrm{KCl}} 4,9$ 5,2 , buvo atlikti tyrimai siekiant išsiaiškinti, kaip iš nuoteku dumblo žaliuju ir bioduju gamybos atlieku pagaminti kompostai turi įtakos pirmaisiais metais po jų ịterpimo auginamų žieminių kviečiu ir antraisiais - vasarinių miežiu grūdu ir šiaudu derliui, jame esančiu azoto, fosforo, kalio bei sunkiuju metalu koncentracijoms. Lauko eksperimentai vykdyti Lietuvos agrarinių ir miškų mokslo centro Elmininkų bandymų stoties (Anykščių r., Rytu Lietuva) laukuose. Tyrimai parodè, kad be mineraliniu trąšu įterpti kompostai pirmaisiais metais augintu žieminių kviečių grūdų ir šiaudų derliaus nedidino. Antraisiais tyrimų metais vasarinių miežių grūdų derlių biodujų gamybos atlieku kompostas didino $72,9 \%$, žaliujų atlieku $-68,6 \%$, galvijų mėšlo - 58,9 \%, nuoteku dumblo 45,2 \%. Mineralinių trąšų fone naudoti kompostai žieminių kviečių ir vasarinių miežių grūdų ir šiaudų derliaus, lyginant su mineralinèmis trąšomis, esmingai nedidino. Cheminių elementų koncentracija augaluose priklausė nuo kompostų irimo proceso dirvožemyje. Pirmaisiais metais po kompostų įterpimo žieminiu kviečių grūduose azoto (N) koncentraciją didino biodujų gamybos atliekų, antraisiais - vasarinių miežių grūduose - nuotekų dumblo ir žaliuju atlieku kompostai. Žieminių kviečiu ir vasariniu miežiu šiauduose kalio (K) koncentraciją didino galviju méšlo, biodujų gamybos atliekų ir nuotekų dumblo kompostai. Pirmaisiais metais visi kompostai didino fosforo (P) koncentraciją žieminiu kviečių šiauduose. Sunkiuju metalu $(\mathrm{Cd}, \mathrm{Ni}, \mathrm{Pb}, \mathrm{Zn}, \mathrm{Mn}$ ir $\mathrm{Cu}$ ) koncentracijos augaluose buvo artimos foniniams lygiams. Naudoti kompostai žieminiuose kviečiuose ir vasariniuose miežiuose kiek labiau padidino nikelio kiekị.

Reikšminiai žodžiai: grūdai, kompostai, sunkieji metalai, šiaudai, vasariniai miežiai, žieminiai kviečiai.

Please use the following format when citing the article:

Staugaitis G., Narutytė I., Arbačauskas J., Vaišvila Z., Rainys K., Mažeika R., Masevičienė A., Žičkienė L., Šumskis D. The influence of composts on yield and chemical elements of winter wheat and spring barley. Zemdirbyste-Agriculture, 103 (4): 355-362 DOI 10.13080/z-a.2016.103.045 